\title{
Model of Queuing in the Railway Level Crossings (Case Study: Railway Level Crossings in Jemursari Surabaya)
}

\author{
Hera Widyastuti' Adita Utami, and Mahardika I. Putra
}

\begin{abstract}
Population growth and the development of economic in Indonesia affect the increase in vehicle volume, especially in the city of Surabaya. The increasing of vehicle volume resulting in increased of direct-access to the city centre and causing arise of new railway level crossings. Furthermore, the increasing of vehicles volume, causing congestion at some points in Surabaya including Jemursari. One of the congestion factors at the railway level crossings is the duration of closing time as the train passes through the crossing. The uncertain duration of gate closing time caused road users to be undisciplined by break through the crossing gates while the train pass through the crossings. Considering of those problems, there are two models has been build, which are: first model is relationship between the length of the train, train velocity, and the closing time of the railway level crossing, and the second model is relationship between the closing time of the railway level crossing and the length of the vehicle queue. Data have been collected and analyse by making model relationship with simple linear regression method. The result shown that there is positive relationship of the train length with the length of gate closing time. However, the train speed has negative relationship. Moreover, length of train has positive relation with the length of queue.
\end{abstract}

Index Terms-Linear regression, railway level crossings, vehicle queue,.

\section{INTRODUCTION}

$T^{1}$ rains in Indonesia have been built since the Dutch colonial era and continue to be developed by the government of Indonesia to cover the demand of railway transportation. It proved by the government through PT. Kereta Api Indonesia (KAI) a State-Owned Enterprise managing railway transportation, continues to make improvements to provide convenience for the railroad users.

Population and economic growth in Indonesia have increased the volume of vehicles in some cities in Indonesia including the city of Surabaya. According to Surabaya Central Bureau of Statistics 2017, the average population growth of Surabaya is $2.136 \%$ per year [1]. Besides, the growth of motor vehicle volume in Surabaya continues to increase by $5-6 \%$

H. Widyastuti is with the Department of Civil Engineering, Institut Teknologi Sepuluh Nopember, Surabaya,Indonesia (e-mail: hera.widyastuti@yahoo.co.uk)

A. Utami is with the Department of Civil Engineering, Institut Teknologi Sepuluh Nopember, Surabaya,Indonesia

M.I.Putra Widyastuti is with the Department of Civil Engineering, Institut Teknologi Sepuluh Nopember, Surabaya,Indonesia. every year [2]. The increasing of vehicle volume resulting in increased of direct-access to the city centre and causing arise of new railway level crossings. Furthermore, the increasing of vehicles volume, causing congestion at some points in Surabaya including Jemursari. This situation happened in accordance with the Law no. 23 of 2007 Article 124 stating that: "In the intersection of a plot between the railway and the road, the road users shall prioritize the train to pass the intersection", so that if there is a crossing between two modes, the road should be closed as the train passes at an intersection [3].

One of the congestion factors at the railway level crossings is the duration of closing time as the train passes through the crossing. The uncertain duration of gate closing time cause road users to be undisciplined by break through the crossing gates while the train pass through the crossings. Closing of the railway level crossing in Raya Jemursari caused congestion on three streets which are: road from Jemursari to Sidoarjo, from Surabaya to Jemursari, and from Sidoarjo to Jemursari. The duration takes by the train to passes through the crossings depends on the length of the train and other factors. Considering of those problems, it is necessary to make a model of relationship between closing of railway level crossing, length and speed of train and length of vehicle queue of in Raya Jemursari, Surabaya.

\section{LITERATURE REVIEW}

\subsection{Crossing/Intersection}

Crossroads (intersection) are two or more sections of a road that meet each other, intersect or cross. The crossing between the road and the railroad is also called the intersection (crossing). The railway crossing is divided into two types. First type is Railway level crossing. According to the regulations of the director general of land transportation number: SK.770 / KA.401 / DRJD / 2005, Railway level crossing is the direct intersection between railway and road [4]. The second type is Railway crossing, according to Road Traffic Planning Guidance with Railway Lane (No: 008 / PW / 2004), Railway crossing is crossing between railway and road in different level [5].

\subsection{Signalized Intersections}

Signalized intersection is an intersection with a Traffic Signal Equipment as a traffic controller. MKJI'97 called the intersection as signaled intersection [6]. The signalized intersection is one of the most complex locations in a traffic 
system. Signalized intersection analysis must consider a wide variety of prevailing conditions [7].

\subsection{Traffic Management}

\subsubsection{Saturation Flow Rate, SO}

The saturation flow rate is the flow in vehicles per hour which could be accommodated by the lane group assuming that the green phase was always available to the approach i.e., that the green ratio, $\mathrm{g} / \mathrm{c}$ was 1 . Computations begin with the selection of an "ideal" saturation flow rate [7]. Formula of Saturation Flow Rate (S0) state in the equation 1.

$$
S=S_{0} x F_{H S} x F_{U K} x F_{G} x F_{P} x F_{B K i} x F_{B K a}
$$

Where:

$\mathrm{S}$ is saturation flow rate for the subject lane group, expressed as a total for all lanes in the lane group under prevailing conditions

S0 is ideal saturation flow rate

$\mathrm{F}_{\mathrm{UK}}$ is adjustment factor for the width of the area

$\mathrm{F}_{\mathrm{HS}}$ is adjustment factor for area type

$\mathrm{F}_{\mathrm{G}}$ is adjustment factor for approach grade

$\mathrm{F}_{\mathrm{P}}$ is adjustment factor for the existence parking lane adjacent to lane group and the parking activity in that lane $F_{B K a}$ is adjustment factor for right turns in the lane group $\mathrm{F}_{\mathrm{BKi}}$ is adjustment factor for left turns in the lane group

\subsubsection{Capacity of Signalized Intersections $(C)$}

Capacity at intersections defined for each approach. Imtersections approach capacity is the maksimum rate of flow which pass through the intersections under prevailing traffic, roadway, and signalized condition. The following equation used to calculate capacity.

$$
C=S \times H / c
$$

Where:

C is capacity of signalized intersection

$\mathrm{S}$ is saturation flow rate for the subject lane group

$\mathrm{H}$ is amount of green ratio in one cycle (second)

c is cycle time (second)

\subsubsection{Degree of Saturation (DS)}

Degree of Saturation is a main parameter used to determine the performance level of service in a road segment. Value of Degree of Saturation (DS) are vary between 0 to 1 [6]. Degree of Saturation can be calculated by using formula below:

$$
D S=Q / c
$$

Where:

DS is $v / c$ ratio for the lane group

$\mathrm{Q}$ is traffic flow

$\mathrm{C}$ is capacity of signalized intersection

\subsubsection{Length of Queue}

The average number of vehicles queue (skr) at the beginning of the green light signal (NQ) is calculated as the number of stopping vehicles (skr) remaining from the previous green phase (NQ1) plus the number of vehicles (skr) coming and stalled in the queue during the red phase NQ2) [6]. Length of the vehicle queue can be calculated using the equation below:

$$
N Q=N Q 1+N Q 2
$$

The queue length $(\mathrm{QL})$ is obtained from the multiplication of NQ (skr) with the average area used by one light vehicle (ekr) which is $20 \mathrm{~m}^{2}$, divided by the entrance width (m) as follows:

$$
P A=N Q \times 20 / L_{M}
$$

\subsubsection{Simple Linear Regression Model}

Regression analysis technique is a technique that can be used to generate relations in numerical form and to generate relations in numerical form and to determine how the variables are interrelated [8]. In a simple linear regression analysis the variables used are expressed in the general form:

$$
Y=a+b x
$$

In this case the Least Squares Method is used in the regression process, wherein the linear line is obtained so that the least squares quantity is generated.

\section{MethodOLOGY}

\subsection{Experimental Objective}

Railway Level Crossing safety is one of the most critical issues for railways. The uncertain duration of gate closing time cause road users to be undisciplined by break through the crossing gates while the train pass through the crossings. One of the congestion factors at the railway level crossings is the duration of closing time as the train passes through the crossing. For all these reasons, Raya Jemursari Railway Level Crossing were selected for our field measurement campaign. For location detailed, can be shown in Fig.1 below:

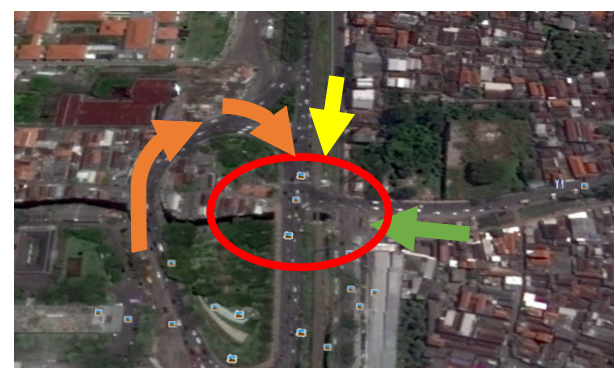

Fig. 1. Location of Raya Jemursari Railway Level Crossing

\subsection{Data Sources and Statistic Method}

The data collection that will be used in this research is primary data and secondary data. The secondary data to support our investigation come from dedicated database provided by PT. Kereta Api Indonesia, while primary data will be obtained by doing direct survey at Jemursari railway level crossing. The road that will be reviewed are Jemursari to Sidoarjo, Surabaya to Jemursari and Sidoarjo to Jemursari. Data collection will be conducted on weekdays and weekends as well as peak hour congestion. Here's the details of data collection and usability: 
TABLE I

TYPES OF DATA AND FUNCTION

\begin{tabular}{|c|c|}
\hline Data Types & Function \\
\hline $\begin{array}{c}\text { Train Schedule that pass through } \\
\text { Railway Level Crossing } \\
\text { (Secondary Data) }\end{array}$ & $\begin{array}{l}\text { To determine the type of the train which pass through the railway level } \\
\text { crossing that affected the closing of gat crossing }\end{array}$ \\
\hline $\begin{array}{c}\text { Length and Train Velocity (Primary } \\
\text { Data) }\end{array}$ & $\begin{array}{l}\text { To determine length and velocity of the train that affected the duration of } \\
\text { gate of railway level crossing closing time }\end{array}$ \\
\hline $\begin{array}{l}\text { Closing time of Railway Level } \\
\text { Crossing (Primary Data) }\end{array}$ & $\begin{array}{l}\text { To determine the duration of gate closing as the train pass through the } \\
\text { railway level crossing. }\end{array}$ \\
\hline Traffic Data (Primary Data) & $\begin{array}{l}\text { To determine the vehicle queue when the of gate of railway level crossing } \\
\text { are closed }\end{array}$ \\
\hline
\end{tabular}

After the data above are collected, data processing will be conducted and divided into two models. First model is relationship between the length of the train, train velocity, and the closing time of the railway level crossing, and the second model is relationship between the closing time of the railway level crossing and the length of the vehicle queue.

Formulation of model relationship between train length, train velocity and closing time of the railway level crossing are conducted by using Linear Regression with SPSS as a supporting software. Furthermore, to formulate the relationship model between the duration of closing Time and the Queue Lines uses 3 (three) regression variants, namely: Linear Regression, Exponential Regression, and Polynomial Regression by using Excel as a supporting software.

\section{Data Analysis}

\subsection{Secondary Data}

In conducted this research study, secondary data which is required are: geometric data of the road and the data of train schedule which passing through the railway level crossing of a jemursari. Geometric data can be shown on Fig. 2 below:

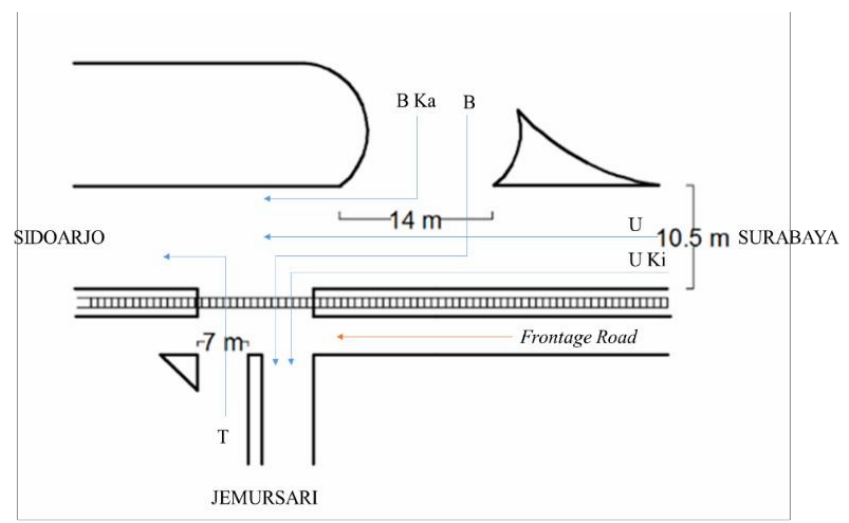

Fig. 2. Geometric Data of Raya Jemursari Railway Level Crossing

After observations and measurements at the Railway Level Crossing of Jemursari was conducted, geometric data obtained in the form of road width from each direction. Moreover, the train schedule that passes through the railway level crossing of Jemursari also collected from PT.Kereta Api Indonesia. Table II shows the schedule of train.

TABLE II

TRAIN SCHEDULE PASSING JEMURSARI RAILWAY LEVEL CROSSING

\begin{tabular}{|c|c|c|c|c|c|c|c|}
\hline \multicolumn{4}{|c|}{ Wonokromo - Waru } & \multicolumn{4}{|c|}{ Waru - Wonokromo } \\
\hline No & No KA & Nama KA & $\begin{array}{c}\text { Jam KA } \\
\text { Lewat JPL }\end{array}$ & No & No KA & Nama KA & $\begin{array}{c}\text { Jam KA } \\
\text { Lewat JPL }\end{array}$ \\
\hline 1 & $2659 \mathrm{~F}$ & Simut & $2: 10$ & 1 & $2660 F$ & Simut & $1: 10$ \\
\hline 2 & 295 & Komuter & $4: 25$ & 2 & $2724 \mathrm{~F}$ & Semen & $2: 28$ \\
\hline 3 & 219 & Probowangi & $4: 38$ & 3 & 90 & Mutiara Timur & $4: 17$ \\
\hline 4 & 459 & Penataran & $4: 55$ & 4 & 2622 & BBM & $5: 58$ \\
\hline 5 & 45 & Bima & $6: 29$ & 5 & 296 & Komuter & $6: 39$ \\
\hline 6 & 471 & KRD SBI-SDA & $7: 21$ & 6 & 460 & Penataran & $6: 50$ \\
\hline 7 & 10939 & Mutiara Selatan & $7: 29$ & 7 & 11040 & Ranggajati & $8: 39$ \\
\hline 8 & 461 & Penataran & $7: 51$ & 8 & 462 & Penataran & $9: 28$ \\
\hline 9 & 87 & Mutiara Timur & $9: 08$ & 9 & 472 & KRD SDA-SBI & $9: 52$ \\
\hline 10 & 463 & Penataran & $11: 46$ & 10 & 190 & Logawa JR & $10: 05$ \\
\hline
\end{tabular}




\begin{tabular}{|c|c|l|c|}
\hline \multicolumn{4}{|c|}{ Wonokromo - Waru } \\
\hline No & No KA & Nama KA & $\begin{array}{c}\text { Jam KA } \\
\text { Lewat JPL }\end{array}$ \\
\hline 11 & 123 & Barang Parcel & $12: 46$ \\
\hline 12 & 2621 & BBM & $13: 19$ \\
\hline 13 & 297 & Komuter & $13: 42$ \\
\hline 14 & 195 & Sri Tanjung BW & $14: 38$ \\
\hline 15 & 189 & Logawa JR & $15: 38$ \\
\hline 16 & 475 & KRD SBI-SDA & $16: 20$ \\
\hline 17 & L2548 & Lokomotif & $17: 04$ \\
\hline 18 & 2623 & BBM & $17: 25$ \\
\hline 19 & 465 & Penataran & $18: 01$ \\
\hline 20 & 299 & Komuter & $18: 14$ \\
\hline 21 & 11060 & Ranggajati & $18: 19$ \\
\hline 22 & 467 & Penataran & $20: 12$ \\
\hline 23 & 2547 & Peti Kemas & $20: 53$ \\
\hline 24 & 49 & Mutiara Timur & $22: 08$ \\
\hline 25 & $2724 \mathrm{~F}$ & Semen & $22: 51$ \\
\hline 26 & 154 & Jayabaya & $23: 36$ \\
\hline
\end{tabular}

\subsection{Primary Data}

Primary which need to be collected such as traffic volume data, data of closing time as the train pass through railway level crossing, and the length and velocity of the railway circuit passing through railway level crossing. In this research, traffic data were collected by doing counting of vehicle volume. Data collection will be done on weekdays and weekends and peak hour respectively. Counting survey will be recorded the vehicle which comes from some direction, which are: from Sidoarjo to Sidoarjo, Sidoarjo to Jemursari, Surabaya to Sidoarjo, Surabaya to Jemursari, and Jemursari to Sidoarjo.

The vehicle volume which is calculated is the volume of light vehicles (LV), heavy vehicles (HV), motorcycles (SM) and un-motorized vehicles (UM). Here is an example of survey results:

\section{a. Vehicle Volume (Weekend)}

TABLE III

EXAMPLE OF VEHICLE VOLUME FROM WEST DIRECTION (WEEKEND)

\begin{tabular}{crrrr}
\hline \multirow{2}{*}{ Time } & \multicolumn{5}{c}{ From Sidoarjo to Jemursari } \\
\cline { 2 - 6 } & LV & HV & SM & UM \\
\hline $15.00-15.15$ & 282 & 5 & 386 & 0 \\
\hline $15.15-15.30$ & 295 & 5 & 380 & 0 \\
\hline $15.30-15.45$ & 250 & 3 & 323 & 0 \\
\hline $15.45-16.00$ & 213 & 2 & 363 & 0 \\
\hline $16.00-16.15$ & 307 & 2 & 484 & 0 \\
\hline $16.15-16.30$ & 152 & 2 & 271 & 0 \\
\hline $16.30-16.45$ & 242 & 2 & 259 & 0 \\
\hline $16.45-17.00$ & 276 & 1 & 370 & 0 \\
\hline Total & 2017 & 22 & 2836 & 0 \\
\hline
\end{tabular}

b. Vehicle Volume (Weekday)

TABLE IV

EXAMPLE OF VEHICLE VOLUME FROM WEST DiRECTION (WEEKDAY)

\begin{tabular}{|c|c|c|c|c|}
\hline \multirow{2}{*}{ Time } & \multicolumn{4}{|c|}{ From Sidoarjo to Jemursari } \\
\hline & LV & $\mathrm{HV}$ & SM & UM \\
\hline $15.00-15.15$ & 172 & 5 & 444 & 0 \\
\hline $15.15-15.30$ & 194 & 5 & 485 & 0 \\
\hline $15.30-15.45$ & 253 & 8 & 445 & 0 \\
\hline $15.45-16.00$ & 212 & 0 & 388 & 0 \\
\hline $16.00-16.15$ & 309 & 0 & 675 & 0 \\
\hline $16.15-16.30$ & 235 & 0 & 677 & 0 \\
\hline $16.30-16.45$ & 237 & 0 & 613 & 0 \\
\hline $16.45-17.00$ & 275 & 0 & 639 & 0 \\
\hline Total & 1887 & 18 & 4366 & 0 \\
\hline
\end{tabular}

\begin{tabular}{|c|c|l|c|}
\hline \multicolumn{4}{|c|}{ Waru - Wonokromo } \\
\hline No & No KA & Nama KA & $\begin{array}{c}\text { Jam KA } \\
\text { Lewat JPL }\end{array}$ \\
\hline 11 & 2624 & BBM & $12: 23$ \\
\hline 12 & 196 & Sri Tanjung BW & $12: 58$ \\
\hline 13 & 154 & Jayabaya & $13: 32$ \\
\hline 14 & 464 & Penataran & $14: 48$ \\
\hline 15 & 88 & Mutiara Timur & $15: 17$ \\
\hline 16 & 46 & Bima & $16: 10$ \\
\hline 17 & 298 & Komuter & $16: 48$ \\
\hline 18 & 476 & KRD SDA-SBI & $17: 48$ \\
\hline 19 & 11016 & Mutiara Selatan & $18: 11$ \\
\hline 20 & 2548 & Peti Kemas & $18: 27$ \\
\hline 21 & 466 & Penataran & $19: 20$ \\
\hline 22 & 124 & Barang Parcel & $19: 57$ \\
\hline 23 & 300 & Komuter & $20: 23$ \\
\hline 24 & 220 & Probowangi & $20: 39$ \\
\hline 25 & L25474 & Lokomotif & $21: 50$ \\
\hline 26 & 468 & Penataran & $22: 21$ \\
\hline \multicolumn{4}{|c}{} \\
\hline
\end{tabular}

c. Traffic Volume which are Passing Through Railway Level Crossing (Weekday)

The volume obtained is the result of the counting survey which conducted by the surveyor. Below is the example of vehicle volume that obtain by traffic counting:

TABLE V

TRAFFIC VOLUME FROM SIDOARJO TO SIDOARJO

\begin{tabular}{clrrc}
\hline \multirow{2}{*}{ Time } & \multicolumn{4}{l}{ Dari Sidoarjo ke Sidoarjo } \\
\cline { 2 - 5 } & LV & HV & SM & UM \\
\hline $15: 20$ & 15 & 1 & 50 & 0 \\
\hline $15: 42$ & 14 & 1 & 48 & 0 \\
\hline $16: 15$ & 16 & 0 & 53 & 0 \\
\hline $16: 25$ & 13 & 1 & 42 & 0 \\
\hline $16: 35$ & 24 & 2 & 61 & 0 \\
\hline $16: 56$ & 11 & 1 & 43 & 0 \\
\hline
\end{tabular}

TABLE VI

TRAFFIC VOLUME FROM SIDOARJO TO JEMURSARI

\begin{tabular}{lllll}
\hline Time & \multicolumn{4}{l}{ From Sidoarjo to Jemursari } \\
\cline { 2 - 5 } & LV & HV & SM & UM \\
\hline $15: 20$ & 79 & 1 & 153 & 0 \\
\hline $15: 42$ & 76 & 3 & 149 & 0 \\
\hline $16: 15$ & 88 & 1 & 159 & 0 \\
\hline $16: 25$ & 71 & 3 & 120 & 0 \\
\hline $16: 35$ & 108 & 4 & 247 & 0 \\
\hline $16: 56$ & 68 & 2 & 118 & 0 \\
\hline
\end{tabular}

d. Traffic Volume which are Passing Through Railway Level Crossing (Weekend)

The volume obtained is the result of the counting which conducted by the surveyor. Below is vehicle volume table:

TABLE VII

TRAFFIC VOLUME FROM SIDOARJO TO SIDOARJO

\begin{tabular}{lllll}
\hline Time & \multicolumn{4}{l}{ From Sidoarjo to Sidoarjo } \\
\cline { 2 - 5 } & LV & HV & SM & UM \\
\hline $15: 22$ & 15 & 1 & 55 & 0 \\
\hline $15: 41$ & 12 & 1 & 40 & 0 \\
\hline $16: 15$ & 18 & 1 & 59 & 0 \\
\hline $16: 50$ & 11 & 1 & 38 & 0 \\
\hline $17: 00$ & 10 & 1 & 37 & 0 \\
\hline
\end{tabular}


TABLE VIII

TRAFFIC VOLUME FROM SIDOARJO TO JEMURSARI

\begin{tabular}{llrrc}
\hline \multirow{2}{*}{ Time } & \multicolumn{4}{l}{ From Sidoarjo to Jemursari } \\
\cline { 2 - 5 } & LV & HV & SM & UM \\
\hline $15: 22$ & 92 & 2 & 163 & 0 \\
\hline $15: 41$ & 68 & 2 & 110 & 0 \\
\hline $16: 15$ & 98 & 3 & 178 & 0 \\
\hline $16: 50$ & 59 & 2 & 92 & 0 \\
\hline $17: 00$ & 52 & 2 & 90 & 0 \\
\hline
\end{tabular}

After vehicle data were collected continued with train length data, train velocity, and duration of gate closing time.
Train length data is calculated from number of trains passing through the Jemursari railway level crossing at $15.00-17.00$ on weekdays and weekends. Train velocity can be calculated from the distance multiplied by the travel time of the train in $\mathrm{km} /$ hour units. As for the closing time obtained by recording the time when the railway level crossing is perfectly closed until the gate open by $45^{\circ}$ in second (s) unit. Below are the results of the survey of train length, velocity, and closing duration of crossing gate:

TABLE IX

Length Velocity of Train Circuit and Duration of Gate Closing Time (WeEkEND)

\begin{tabular}{rrrlll}
\hline \multicolumn{1}{l}{ Time } & Train Name & Train Number & Duration & Amount of Train & Velocity(km/hour) \\
\hline $15: 22$ & Mutiara & 88 & 115 & 11 & 70 \\
\hline $15: 41$ & Hogawa & 189 & 82 & 10 & 70 \\
\hline $16: 15$ & Bima & 46 & 140 & 11 & 70 \\
\hline $16: 50$ & KRD & 475 & 78 & 6 & 70 \\
\hline $17: 00$ & Barang & 298 & 75 & 4 & 50 \\
\hline $15: 22$ & Komuter & 88 & 115 & 11 & 70 \\
\hline
\end{tabular}

TABLE X

LENGTh, Velocity of TRAin CirCUIT AND DURATION OF GATE Closing Time (WEEKDAY)

\begin{tabular}{clllll}
\hline Time & Train Name & Train Number & Duration & Amount of Train \\
\hline $15: 20$ & Mutiara & 88 & 98 & 10 \\
\hline $15: 42$ & Hogawa & 189 & 96 & 10 & \\
\hline $16: 15$ & Bima & 46 & 109 & 11 & \\
\hline $16: 25$ & KRD & 475 & 94 & 6 & \\
\hline $16: 35$ & Barang & 298 & 186 & 21 \\
\hline $16: 56$ & Komuter & 298 & 86 & 4 & \\
\hline
\end{tabular}

Next step is measure the vehicle queue length which is measured by using roll meter. The measurement conducted when the signal lamp turns red while the train passing through the railway level crossing. Measurement were conducted in every direction. Below are the result of the queue length measurement in meter $(\mathrm{m})$ units:

TABLE XI

LENGTH OF QUeUe AT THE RAILWAY LEVEL CROSSING (WEEKEND)

\begin{tabular}{cccll}
\hline \multirow{2}{*}{ Time } & \multirow{2}{*}{ Duration (s) } & \multicolumn{3}{l}{ Queue Length $(\mathrm{m})$} \\
\cline { 3 - 5 } & & North (Left) & West & East \\
\hline $15: 22$ & 115 & 56 & 151 & 310 \\
\hline $15: 41$ & 82 & 45 & 125 & 245 \\
\hline $16: 15$ & 140 & 58 & 161 & 340 \\
\hline $16: 50$ & 78 & 35 & 110 & 232 \\
\hline $17: 00$ & 75 & 30 & 102 & 230 \\
\hline
\end{tabular}

TABLE XII

LENGTH OF QUEUE AT THE RAILWAY LEVEL CROSSING (WEEKEDAY)

\begin{tabular}{|c|c|c|c|c|}
\hline \multirow{2}{*}{ Time } & \multirow{2}{*}{ Duration (s) } & \multicolumn{3}{|c|}{ Queue Length (m) } \\
\hline & & North (Left) & West & East \\
\hline & 098 & 50 & 146 & 298 \\
\hline & 296 & 47 & 134 & 285 \\
\hline & 5109 & 55 & 150 & 315 \\
\hline & 594 & 45 & 132 & 280 \\
\hline & 5186 & 63 & 170 & 351 \\
\hline & 686 & 46 & 120 & 270 \\
\hline
\end{tabular}

\section{RESUltS AND ANALYSIS}

5.1. Traffic Analysis

After determined amount of vehicle, calculation of light vehicle will be done, and so does the vehicle ratio, until the capacity of each direction and the saturation degree are found. From that analysis, the length of the vehicle queue also can be determined. The following table will show the capacity and DS at the Jemursari signalized Intersection.

TABLE XIII

CAPACITY AND DEGREE OF SATURATION (WEEKDAY)

\begin{tabular}{ccccc}
\hline $\begin{array}{c}\text { Each } \\
\text { direction }\end{array}$ & Phase & $\begin{array}{c}\text { Q (smp/ } \\
\text { hour })\end{array}$ & $\begin{array}{c}\mathrm{C}(\mathrm{smp} / \\
\text { hour })\end{array}$ & $\mathrm{D}$ \\
\hline $\mathrm{B}$ & 1 & 1826 & 1672 & 1.09 \\
\hline $\mathrm{U}$ & $2 \& 3$ & 2957 & 2068 & 1.43 \\
\hline $\mathrm{U} \mathrm{Ki}$ & $1 \& 2$ & 172 & 685 & 0.25 \\
\hline $\mathrm{T}$ & $1 \& 2$ & 1500 & 1374 & 1.09 \\
\hline
\end{tabular}

TABLE XIV

CAPACITY AND DEGREE OF SATURATION (WEEKEND)

\begin{tabular}{ccccc}
\hline $\begin{array}{c}\text { Each } \\
\text { direction }\end{array}$ & Phase & Q (smp/hour) & $\begin{array}{c}\mathrm{C}(\mathrm{smp} / \\
\text { hour) }\end{array}$ & $\mathrm{D}$ \\
\hline $\mathrm{B}$ & 1 & 2134 & 1935 & 1.10 \\
\hline $\mathrm{U}$ & $2 \& 3$ & 3026 & 2099 & 1.44 \\
\hline $\mathrm{U} \mathrm{Ki}$ & $1 \& 2$ & 164 & 696 & 0.24 \\
\hline $\mathrm{T}$ & $1 \& 2$ & 1538 & 1395 & 1.10 \\
\hline
\end{tabular}


5.2. Traffic Analysis when Train Passing through Railway Level Crossing

Traffic analysis when the train passing through railway level crossing is about the same with the proceeding traffic analysis, which is using PKJI 2014. But, in this sub-chapter will be shown the result of data analysis calculation and the vehicle queue length when the series of train passing through intersection.

TABLE XV

CAPACITY AND SATURATION DEGREE WHEN TRAIN PASSING THROUGH INTERSECTION (WEEKDAY)

\begin{tabular}{ccccccc}
\hline \multirow{2}{*}{ Direction Code } & \multicolumn{2}{c}{$15: 20$} & \multicolumn{2}{c}{$15: 42$} & \multicolumn{2}{c}{$16: 15$} \\
\cline { 2 - 7 } & Capacity & DS & Capacity & DS & Capacity & DS \\
\hline $\mathrm{B}$ & 1397 & 1.25 & 1300 & 1.18 & 1499 & 1.28 \\
\hline $\mathrm{U}$ & 2126 & 0.81 & 2194 & 0.73 & 2122 & 0.80 \\
\hline $\mathrm{U} \mathrm{Ki}$ & 697 & 0.36 & 720 & 0.32 & 695 & 0.38 \\
\hline $\mathrm{T}$ & 1413 & 1.25 & 1458 & 1.18 & 1410 & 1.28 \\
\hline \multirow{2}{*}{ Direction Code } & \multicolumn{2}{c}{$16: 25$} & \multicolumn{2}{c}{$16: 35$} & \multicolumn{2}{c}{$16: 56$} \\
\cline { 2 - 8 } & Capacity & DS & Capacity & DS & Capacity & DS \\
\hline $\mathrm{B}$ & 1450 & 1.17 & 1433 & 1.32 & 1419 & 1.16 \\
\hline $\mathrm{U}$ & 2224 & 0.70 & 2115 & 0.79 & 2212 & 0.71 \\
\hline $\mathrm{U} \mathrm{Ki}$ & 730 & 0.31 & 694 & 0.44 & 725 & 0.31 \\
\hline $\mathrm{T}$ & 1478 & 1.17 & 1405 & 1.32 & 1470 & 1.16 \\
\hline
\end{tabular}

TABLE XVI

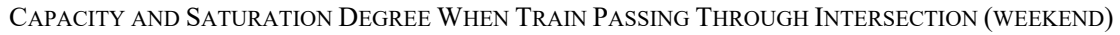

\begin{tabular}{|c|c|c|c|c|c|c|}
\hline \multirow{2}{*}{ direction code } & \multicolumn{2}{|c|}{$15: 22$} & \multicolumn{2}{|c|}{$15: 41$} & & \\
\hline & Capacity & DS & Capacity & DS & & \\
\hline $\mathrm{B}$ & 1203 & 1.30 & 1457 & 1.11 & & \\
\hline $\mathrm{U}$ & 2102 & 0.82 & 2212 & 0.73 & & \\
\hline $\mathrm{U} \mathrm{Ki}$ & 690 & 0.39 & 728 & 0.31 & & \\
\hline $\mathrm{T}$ & 1397 & 1.30 & 1470 & 1.11 & & \\
\hline \multirow{2}{*}{ Direction Code } & \multicolumn{2}{|c|}{$16: 15$} & \multicolumn{2}{|r|}{$16: 50$} & \multicolumn{2}{|c|}{$17: 00$} \\
\hline & Capacity & DS & Capacity & DS & Capacity & DS \\
\hline B & 1513 & 1.32 & 1420 & 1.04 & 1336 & 1.01 \\
\hline U & 2129 & 0.77 & 2317 & 0.62 & 2345 & 0.60 \\
\hline $\mathrm{U} \mathrm{Ki}$ & 697 & 0.40 & 762 & 0.26 & 772 & 0.24 \\
\hline $\mathrm{T}$ & 1414 & 1.32 & 1539 & 1.04 & 1558 & 1.01 \\
\hline
\end{tabular}

\subsection{Queue Length}

The average amount of vehicle (skr) at the beginning of green light signal (NQ) is counted as the amount of stopped vehicle (skr) which was left behind from the previous green phase (NQ1) plus the amount of vehicle (skr) that will come and stop in line in the red phase (NQ2) The following table is the result of the line length using PKJI at the working day and weekend at the railway level crossing at Raya Jemursari.

TABLE XVII

Vehicle Line Length (M) When Train Passing Through The Intersection (WeEkday)

\begin{tabular}{|c|c|c|c|c|c|c|c|c|c|c|c|c|}
\hline \multirow{2}{*}{ Direction Code } & \multicolumn{4}{|c|}{$15: 20$} & \multicolumn{4}{|c|}{$15: 42$} & \multicolumn{4}{|c|}{$16: 15$} \\
\hline & NQ1 & NQ2 & NQ & $\mathrm{PA}$ & NQ1 & NQ2 & NQ & $\mathrm{PA}$ & NQ1 & NQ2 & NQ & $\mathrm{PA}$ \\
\hline $\mathrm{B}$ & 15 & 84 & 99 & 142 & 12 & 73 & 85 & 122 & 17 & 93 & 110 & 158 \\
\hline $\mathrm{U}$ & 11 & 71 & 82 & 156 & 15 & 64 & 79 & 150 & 11 & 70 & 81 & 155 \\
\hline $\mathrm{U} \mathrm{Ki}$ & 0 & 8 & 8 & 48 & 0 & 8 & 8 & 44 & 0 & 9 & 9 & 52 \\
\hline $\mathrm{T}$ & 15 & 93 & 108 & 309 & 12 & 88 & 100 & 286 & 17 & 97 & 114 & 326 \\
\hline \multirow{2}{*}{ Direction Code } & \multicolumn{4}{|c|}{$16: 25$} & \multicolumn{4}{|c|}{$16: 35$} & \multicolumn{4}{|c|}{$16: 56$} \\
\hline & NQ1 & NQ2 & NQ & $\mathrm{PA}$ & NQ1 & NQ2 & NQ & PA & NQ1 & NQ2 & NQ & PA \\
\hline B & 11 & 80 & 91 & 131 & 20 & 93 & 113 & 161 & 11 & 78 & 89 & 128 \\
\hline $\mathrm{U}$ & 17 & 60 & 77 & 147 & 12 & 69 & 81 & 154 & 16 & 62 & 78 & 149 \\
\hline $\mathrm{U} \mathrm{Ki}$ & 0 & 8 & 8 & 43 & 0 & 11 & 11 & 61 & 0 & 7 & 7 & 43 \\
\hline $\mathrm{T}$ & 11 & 87 & 98 & 281 & 20 & 103 & 123 & 350 & 11 & 86 & 97 & 278 \\
\hline
\end{tabular}


TABLE XVIII

Vehicle LiNe LeNGTH (M) WHEN TRAin PASSing Through The INTERSECTION (WEeKEND)

\begin{tabular}{|c|c|c|c|c|c|c|c|c|c|c|c|c|}
\hline \multirow{2}{*}{$\begin{array}{c}\text { Direction } \\
\text { Code }\end{array}$} & \multicolumn{4}{|c|}{$15: 22$} & \multicolumn{4}{|c|}{$15: 41$} & & & & \\
\hline & NQ1 & NQ2 & NQ & $\mathrm{PA}$ & NQ1 & NQ2 & NQ & $\mathrm{PA}$ & & & & \\
\hline B & 19 & 75 & 94 & 134 & 9 & 76 & 85 & 122 & & & & \\
\hline $\mathrm{U}$ & 10 & 72 & 82 & 157 & 15 & 64 & 79 & 151 & & & & \\
\hline $\mathrm{U} \mathrm{Ki}$ & 0 & 9 & 9 & 54 & 0 & 8 & 8 & 43 & & & & \\
\hline $\mathrm{T}$ & 19 & 99 & 118 & 337 & 9 & 80 & 89 & 255 & & & & \\
\hline \multirow{2}{*}{$\begin{array}{l}\text { Direction } \\
\text { Code }\end{array}$} & \multicolumn{4}{|c|}{$16: 15$} & \multicolumn{4}{|c|}{$16: 50$} & \multicolumn{4}{|c|}{$17: 00$} \\
\hline & NQ1 & NQ2 & $\mathrm{NQ}$ & $\mathrm{PA}$ & NQ1 & NQ2 & NQ & $\mathrm{PA}$ & NQ1 & NQ2 & NQ & $\mathrm{PA}$ \\
\hline B & 19 & 98 & 117 & 168 & 7 & 68 & 75 & 108 & 7 & 62 & 69 & 98 \\
\hline $\mathrm{U}$ & 13 & 67 & 80 & 152 & 22 & 54 & 76 & 144 & 23 & 52 & 75 & 143 \\
\hline $\mathrm{U} \mathrm{Ki}$ & 0 & 10 & 10 & 55 & 0 & 6 & 6 & 36 & 0 & 6 & 6 & 32 \\
\hline $\mathrm{T}$ & 19 & 103 & 122 & 349 & 7 & 75 & 82 & 236 & 7 & 73 & 80 & 228 \\
\hline
\end{tabular}

\subsection{Model Equality}

The model equality in this research is the relation model with regression for train length, train velocity and length of railway level crossing closing time, and relation model of the length of railway level crossing closing time with the length of real on-field line and PKJI calculation.

5.5.1 Relation Model between Train Length, Velocity, and Duration of Closing Time

Model equation that formulated using SPSS as supporting device is

$\mathrm{Y}=90.857+6.232 \mathrm{X}_{1}-0.682 \mathrm{X}_{2}$

$\mathrm{Y}$ : Length of railway level crossing closing time

$\mathrm{X}_{1}$ : Train Length

$\mathrm{X}_{2}$ : Train Speed

The equation means every additional length of train means additional closing time equals to 6.232 seconds, and -0.682 means the velocity of train has negative effect for the length of railway level crossing closing time, meaning additional velocity equals to $1 \mathrm{~km} / \mathrm{h}$ will add the railway level crossing closing time equals to $-0,682 \mathrm{~s}$.

5.5.2 Relation Model between Closing Time and Vehicle Queue Length

Equation of relationship model of closing time and queue length divide into three, equals with direction that has been calculated, which is north direction to turn left and west direction and east direction.

Model designed based on three variant of regression, which is exponential regression, linear regression and polynomial regression using supporting software such as Ms. Excel. Here's the model:

TABLE XIX

TABLE OF RELATION MODEL SUMMARY

\begin{tabular}{llll}
\hline \multicolumn{4}{l}{ Relationship between closing duration of railway level crossing and queue length on North (turn left) direction } \\
based on real condition
\end{tabular}




\begin{tabular}{|c|c|c|c|}
\hline \multicolumn{4}{|c|}{$\begin{array}{c}\text { Relationship between closing duration of railway level crossing and queue length on East direction based on } \\
\text { real condition }\end{array}$} \\
\hline No & Regression Method & Model Equation & R-Sq Value \\
\hline 1. & Exponential & $y=190.21 e^{0.0038 x}$ & 0.7457 \\
\hline 2. & Linear & $y=1.1137 x+169.57$ & 0.7916 \\
\hline 3. & Polynomial & $y=-0.0157 x^{2}+5.1564 x-66.624$ & 0.9723 \\
\hline \multicolumn{4}{|c|}{$\begin{array}{l}\text { Relationship between closing duration of railway level crossing and queue length on East direction based on } \\
\text { PKJI } 2014\end{array}$} \\
\hline No & Regression Method & Model Equation & R-Sq Value \\
\hline 1. & Exponential & $y=195.37 \mathrm{e}^{0.0038 x}$ & 0.6614 \\
\hline 2. & Linear & $y=1.1163 x+176.44$ & 0.6975 \\
\hline 3. & Polynomial & $y=-0.0205 x^{2}+6.3784 x-131$ & 0.9662 \\
\hline
\end{tabular}

Using that summary table, it can be seen that all of the R-Sq which almost reaching value 1 (one) is the model from polynomial regression. But, because polynomial regression can cause negative value, then the most correct regression that can be used is linear regression.

TABLE XX

BEST RELATION MODEL

\begin{tabular}{llr}
\hline \multicolumn{1}{c}{ Direction Code } & \multicolumn{1}{c}{ Real Model } & PKJI Model \\
\hline North Left & $\mathrm{y}=0.2529 \mathrm{x}+21.538$ & $\mathrm{y}=0.2315 \mathrm{x}+22.179$ \\
\hline West & $\mathrm{y}=0.5721 \mathrm{x}+76.18$ & $\mathrm{y}=0.5409 \mathrm{x}+76.659$ \\
\hline East & $\mathrm{y}=1.1137 \mathrm{x}+169.57$ & $\mathrm{y}=1.1163 \mathrm{x}+176.44$ \\
\hline
\end{tabular}

\section{CONCLUSIONS}

Few conclusion that can be drawn from the result that has been made in this research. For the first model, the result of relation regression between the length of the train and length of railway level crossing closing time has significant affection. In the other hand, the relation of the train velocity has negative affection to railway level crossing closing time, with the model of those three factors are $\mathrm{y}=90.857+6.232 \mathrm{x}_{1}-0.682$ $\mathrm{x}_{2}$. Where $\mathrm{y}$ is the length of closing time, $\mathrm{x}_{1}$ is the train length and $\mathrm{x}_{2}$ is train velocity. Moreover, for the second model the regression result between railway level crossing closing time with the line length in every direction on Jemursari intersection has positive relation with the model $\mathrm{y}=0.2315 \mathrm{x}+$ 22.179 for the North direction to turn left, $\mathrm{y}=0.5409 \mathrm{x}+$ 76.659 for West direction and $y=1.1163 x+176.44$ for East direction. $\mathrm{Y}$ is the line length of vehicle and $\mathrm{x}$ is the length of closing time.

\section{REFERENCES}

[1] Badan Pusat Statistik. "Statistik Pertumbuhan volume kendaraan Surabaya," Surabaya: BPS, 2017.

[2] Badan Pusat Statistik. "Statistik Pertumbuhan volume kendaraan Surabaya," Surabaya: BPS. 2016

[3] Departemen perhubungan. "Undang-undang No 23 Tahun 2007 tentang Perkeretaapian," Jakarta: Dephub, 2007.

[4] Direktur Jenderal Perhubungan Darat. " Peraturan Direktur Jenderal Perhubungan Darat nomor: SK.770/KA.401/DRJD/2005,” Jakarta, 2005.

[5] Direktorat Jenderal Prasarana Wilayah. "Wilayah Pedoman Perencanaan Perlintasan Jalan dengan Jalur Kereta Api (No:008/PW/2004), , Jakarta, 2004.

[6] Kementerian Pekerjaan Umum. "Panduan Kapasitas Jalan Indonesia," Jakarta, 2014

[7] Transportation Research Board National Research Council. "Highway Capacity Manual," Washington D.C, 1985.

[8] Tamin, O.Z. "Perencanaan dan Pemodelan Transportasi," Second Edition, Bandung : ITB, 2000. 